International Journal of Life Sciences
Available online at www.sciencescholar.us
Vol. 5 No. 3, December 2021, pages: $171-178$
e-ISSN: 2550-6986, p-ISSN: 2550-6994
https://doi.org/10.53730/ijls.v5n3.1721

\title{
The Potential Cancer Risk on Body Organs as Abdomen CT-Scan Exposure Result
}

\author{
(1) Cross Mark \\ Ida Bagus Made Suryatika a, S. Poniman b, Ida Bagus Putra Manuaba c, I Wayan Putu Sutirta Yasa d, \\ Gusti Ngurah Sutapa ${ }^{\mathrm{e}}$
}

Manuscript submitted: 18 August 2021, Manuscript revised: 09 September 2021, Accepted for publication: 27 October 2021

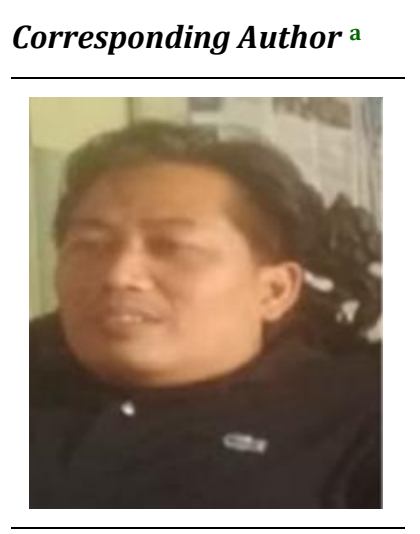

Keywords

body organs;

cancer risk;

CT-scan;

exposure;

radiation;

\section{Abstract}

Research has been carried out on the Potential Risk of Cancer in Body Organs Due to Abdomen CT Scan Radiation. The use of a CT-Scan tool that emits radiation has the potential to have quite a serious impact. An abdominal CTScan is one part of the examination that is often done because in that section many organs are very vital. The organs found in the abdomen include the liver, spleen, stomach, intestines, kidneys, gonads, pancreas, bladder, and ureters. The study used data on abdominal CT-Scan patients at Sanglah Hospital Denpasar, in the age range from 41 years to 56 years without distinguishing gender. From the CT-Scan data, the CTDIVol and DLP values?? of each patient can be taken. Furthermore, it is analyzed to determine the patient's effective dose so that the percentage of cancer risk in each of these organs can be known. The results showed that the potential risk of cancer for critical organs such as the bladder, stomach, and gonads, was $0.218 \%, 0.262 \%$, and $0.390 \%$ respectively. The most at risk for potential cancer occurs in the gonads.

International Journal of Life Sciences (c) 2021. This is an open access article under the CC BY-NC-ND license (https://creativecommons.org/licenses/by-nc-nd/4.0/).

\section{Contents}

Abstract 171

1 Introduction.... 172

2 Materials and Methods 172

a Physics Faculty of Mathematics and Natural Sciences, Udayana University, Denpasar, Indonesia

b Physics Faculty of Mathematics and Natural Sciences, Udayana University, Denpasar, Indonesia

c Chemical Faculty of Mathematics and Natural Sciences, Udayana University, Denpasar, Indonesia

d Biochemistry Faculty of Medical, Udayana University, Denpasar, Indonesia

e Physics Faculty of Mathematics and Natural Sciences, Udayana University, Denpasar, Indonesia 


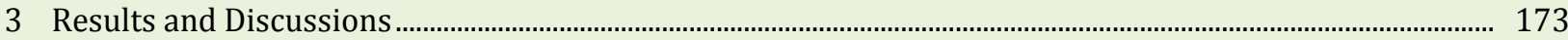

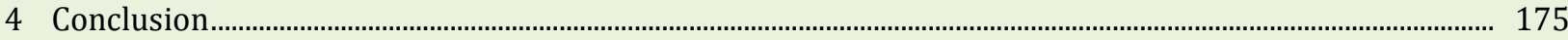

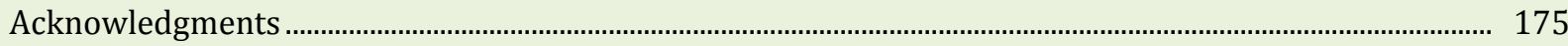

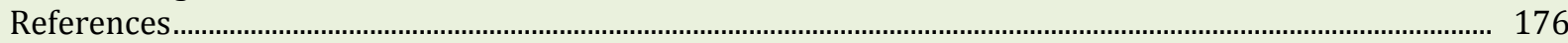

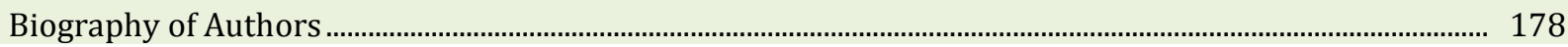

\section{Introduction}

In the scanning process, the patient will receive radiation from the CT-Scan aircraft, so it is necessary to calculate the amount of radiation dose using the Computed Tomography Dose Index (CTDI) method received by the patient at each examination (Tsalafoutas \& Metallidis, 2011). The lowest radiation dose received by the patient will cause changes in the biological system and the risk of cancer that is obtained by the sensitive organs in the patient's body. The biological effect of radiation does not only depend on the dose of radiation that hits the tissue or organ but also depends on the biological sensitivity of the tissue or organ exposed to radiation, which is called the effective dose. The effective dose is a reflection of the radiation dose reflected from different biological sensitivities (Chuninghum, 1983). So, it is necessary to estimate the radiation dose to determine the percentage of potential cancer risk received by the patient due to the ionizing radiation emitted on a CT-Scan examination (Adler et al., 1992; Martina, 2016).

Several factors that influence radiation dose and can be controlled are x-raying tube, current and voltage, rotation time, helical pitch, slice thickness, scan duration, and dose adjustment technique (Pimblott \& LaVerne, 2007; Czvikovszky, 2003). The single parameter that describes the risk of exposure to ionizing radiation given to patients from various CT-scan planes is the effective dose. The effective dose describes the risk of adverse biological effects from radiation exposure. The Dose Length Product/Effective Dose (DLP/ED) conversion coefficient for CT-Scan aircraft was first published in Europe in 1999. The available DLP/ED conversion coefficients are for the head, neck, chest, abdomen, and pelvis (Silvia et al., 2013). This research aims to determine the effective dose of the patient's organs for abdominal CT-Scan examination. Furthermore, this research also determines the potential risk of cancer that is received by the patient every time he performs an abdominal examination with CT-Scan modalities (Sofiana, 2013; Strauss \& Rae, 2012).

\section{Materials and Methods}

The research was conducted at the Radiology and Radiodiagnostic Imaging Installation of Sanglah Hospital with the tools used in this study were CT-Scan, CR (Computer Radiography), Lux meter, Humidity meter, Thermometer, and patient medical records. Meanwhile, data analysis was carried out at the Biophysics and Medical Physics Laboratory, Bukit Jimbaran Campus (Susilo \& Setiowati, 2012; Sutapa et al., 2018).

In identifying the amount of dose received by the patient, data were taken from adult patients aged 41 to 56 years without distinguishing gender. Each type of examination requires data of at least 20 patients for each type of examination that is frequent or multiple (Hardt et al., 1999; Crawford et al., 2012). If the facility can estimate the workload of patients per type of examination for each modality, then the number of patient samples required is at least $30 \%$ of the workload. In this study, a Siemens 128 CT scanner was used with a slice thickness of $10 \mathrm{~mm}$ and a voltage of $120 \mathrm{kV}$, a tube current of $35 \mathrm{~mA}$, a slice thickness of $10 \mathrm{~mm}$, and a scan length of $32 \mathrm{~cm}$ which functioned as an X-ray generator. Computer and CT-Scan console to display and save and record the resulting images in 3 dimensions. For abdominal CT-Scan examination, the patient's dose estimate can use CTDI and DLP. CTDI and DLP values can generally be seen on the CT scan console monitor screen or integrated with the DICOM data system (Cosnier et al., 2014; Kamalzadeh et al., 1998).

The patient's medical record data displayed on the monitor screen or DICOM data is quantitative data that is analyzed comparatively and statistically, by looking at and comparing the results of observations from the research conducted. Data from medical records, especially DLP and CTDI values, were then analyzed to determine the CTDIeff value, then estimated the potential risk of cancer with the Riskeff value. The statistical analysis used was ANOVA (Analysis of Variance). The results of the ANOVA test that were significantly 
different $(\mathrm{P} \leq 0.05)$ were continued with the LSD test so that a significant difference could be seen between the Riskeff values of each patient's organs (Vasen et al., 1996; Belfiore et al., 1992).

\section{Results and Discussions}

The results of the abdominal CT-Scan patient examination for the category of adult patients can be shown in the following table 1 :

Table 1

CT-Scan patient examination for the category of adult patients

\begin{tabular}{llccccc}
\hline \multirow{2}{*}{ No. } & \multicolumn{1}{c}{ Patients ID } & Patient Age & \multicolumn{2}{c}{ Eksposi } & CTDIvol & DLP \\
& & 43 & 56 & 120 & 7,28 & 232,96 \\
\hline 1 & Ni Wayan Rindi & 42 & 70 & 120 & 6,03 & 192,96 \\
2 & Komang Kari & 45 & 77 & 120 & 7.66 & 245.12 \\
3 & I Nyoman Nastra & 45 & 40 & 120 & 4.11 & 131,52 \\
4 & Riana Astari & 46 & 75 & 120 & 7.90 & 252,80 \\
5 & Sugeng Hendrajaya & 43 & 56 & 120 & 5.30 & 169,60 \\
6 & Ni Gst Putu Rai I & 48 & 40 & 120 & 4.08 & 130,56 \\
7 & Ni Nengah Pondri & 56 & 70 & 120 & 8.33 & 266,56 \\
8 & I Ketut Paja & 51 & 55 & 120 & 8.28 & 264,96 \\
9 & I Made Mandiarta & 50 & 67 & 120 & 7.42 & 237,44 \\
10 & Ni Wayan Asri & 52 & 56 & 120 & 7.26 & 232,32 \\
11 & Ni Ketut Kormi & 45 & 45 & 120 & 5.30 & 169,60 \\
12 & Ni Nengah Purwati & 47 & 48 & 120 & 6.39 & 204,48 \\
13 & Jumahir & 55 & 70 & 120 & 7.90 & 252,80 \\
14 & I Wayan Arpa & 48 & 65 & 120 & 6.33 & 202,56 \\
15 & Marsinah & 48 & 75 & 120 & 7.03 & 224,96 \\
16 & Ni Nyoman Teblun & 53 & 60 & 120 & 7.32 & 234,24 \\
17 & Wayan Tegal & 41 & 55 & 120 & 6.71 & 214,72 \\
18 & I Wayan Oka & 55 & 66 & 120 & 8.41 & 269,12 \\
19 & I Gst Ketut Suarta & 45 & 45 & 120 & 5.38 & 172,16 \\
20 & Ni Ketut Dangin & & & & & \\
\hline
\end{tabular}

The results of the measurement of the abdominal CT-Scan as shown in the table above can then be determined the effective dose (Raidanti et al., 2021; Sutapa et al., 2021). As an example of the calculation, the patient data was taken on behalf of Ni Wayan Rindi, with a scan length of $32 \mathrm{~cm}$ where the CTDIvol value was $7.28 \mathrm{mGy}$ and DLP 232.96 mGy.cm. Critical organs that can be determined effective dose on abdominal examination are stomach with organ weight factor $(w t=0.12)$, gonads wt $=0.08$ ) and bladder (urinary bladder- $w t=0.04$ ).

$$
\begin{aligned}
D_{\text {eff }} & =C T D I_{\text {vol }} \times w_{t} \\
& =7,28 \mathrm{mGy} \times 0,12(\text { stomach }), \text { with } 1 \mathrm{mGy} \text { can be converted to } 1 \mathrm{mSv} \\
& =0,873 \mathrm{mSv} \\
& =7,28 \mathrm{mGy} \times 0,08(\text { gonard }), \\
& =0,582 \mathrm{mSv} \\
& =7,28 \mathrm{mGy} \times 0,04(\text { bladder }), \\
& =0,291 \mathrm{mSv}
\end{aligned}
$$

Furthermore, it can be determined the potential risk of cancer with the risk for stomach is 30 , gonard 67 and bladder 75 , using the following equation:

Suryatika, I. B. M., Poniman, S., Manuaba, I. B. P., Yasa, I. W. P. S., \& Sutapa, G. N. (2021). The potential cancer risk on body organs as abdomen CT-scan exposure result. International Journal of Life Sciences, 5(3), 171-178. 


$$
\begin{aligned}
\text { Risk }_{\text {eff }} & =D_{\text {eff }} \times r_{t} \\
& =0,873 \mathrm{mSv} \times 30(\text { stomach }) \\
& =26,19 \mathrm{mSv}=0,262 \% \\
& =0,582 \mathrm{mSv} \times 67(\text { gonard }) \\
& =38,99 \mathrm{mSv}=0,390 \% \\
& =0,291 \mathrm{mSv} \times 75(\text { bladder }) \\
& =21,82 \mathrm{mSv}=0,218 \%
\end{aligned}
$$

The full potential risk of cancer for each critical organ on abdominal examination is shown in the following table 2.

Table 2

Potential cancer risk for critical organs in abdominal examination patients

\begin{tabular}{lcc}
\hline \multicolumn{1}{c}{ Critical Organ } & $\begin{array}{c}\text { Effective Dose } \\
(\mathrm{mSv})\end{array}$ & Potential Cancer Risk \\
& 0,291 & 0,218 \\
\hline Bladder & 0,873 & 0,262 \\
Stomach & 0,582 & 0,390 \\
Gonads & & \\
\hline
\end{tabular}

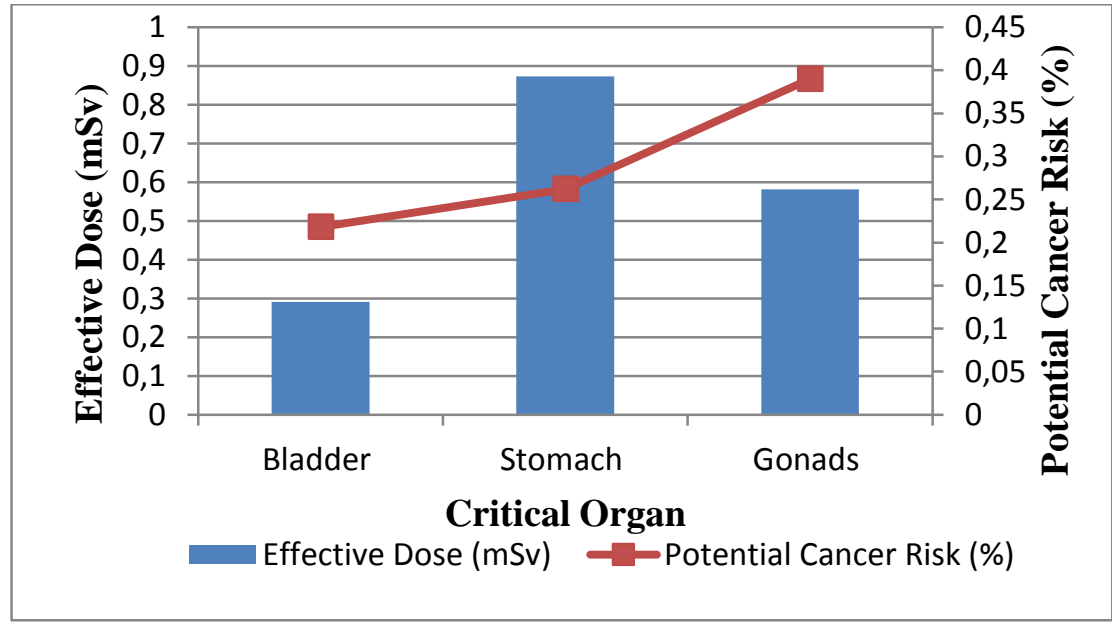

Figure 1. Effective dose and potential cancer risk to critical organs

The effective dose for critical organs for abdominal CT-Scan examination is shown in Figure 1, that the largest effective dose is found in the stomach organ and shows a decrease in the gonads organ and the lowest effective dose occurs in the bladder organ. This is influenced by the mass of the gastric organ which is smaller than the mass of the gonads and bladder organs, although the weight factor of the stomach is greater than that of the gonads and bladder (ICRP, 2011). This condition is also in accordance with the theory that the radiation dose is affected by the average energy given by ionizing radiation of $\mathrm{dE}$ to the material in its path with a mass of $\mathrm{dm}$ (Chuninghum, 1983).

The results of the study for potential cancer risk are shown in Figure 1. It also follows the ICRP 103 literature, that the potential risk of developing cancer in a patient can be estimated by assuming a doseresponse or effective dose relationship (Tan et al., 1998; Keyak \& Falkinstein, 2003). The highest effective dose on abdominal CT-Scan examination was in the stomach organ of $0.873 \mathrm{mSv}$ with a potential cancer risk of $0.262 \%$ and followed by the gonads organ of $0.582 \mathrm{mSv}$ with a potential cancer risk of $0.390 \%$, and the lowest bladder organ with an effective dose of $0.291 \mathrm{mSv}$ and a potency of cancer risk of $0.218 \%$. The difference between the effective dose received by critical organs and the potential cancer risk that occurs is caused by differences in cancer risk factors possessed by each of these critical organs (ICRP, 2011). This significant difference was also shown from the results of statistical analysis $(\mathrm{P} \leq 0.05)$. The highest risk of 
cancer occurs in the gonads organ and is followed by the stomach organ and the lowest organ of cancer risk is bladder. The results of this study indicate that the estimated potential for cancer in abdominal CT-Scan patients is still a small percentage. This is because the abdominal CT-Scan examination is carried out only 1 time and is also influenced by the relatively small current strength value with the X-ray tube voltage used the same for each examination (Suryatika et al., 2020).

\section{Conclusion}

CT-Scan examination of the abdomen caused critical organs such as the stomach, gonads and bladder to have received effective doses of $0.873 \mathrm{mSv}, 0.582 \mathrm{mSv}$ and $0.291 \mathrm{mSv}$, respectively, with the potential risk of cancer reaching $0.262 \%, 0.390 \%$ and $0.218 \%$. The stomach is a critical organ that has the highest potential risk of cancer compared to other organs for a single abdominal CT-Scan examination, however, the potential risk of cancer that occurs is still much lower than the ICRP 103, 2011 recommendation of 5.5\%.

\section{Acknowledgments}

Acknowledgments to Udayana University for funding the implementation of this research through the Unud DIPA PNBP in the fiscal year 2021 following the Letter of Appointment for the Study Program Leading Research (PUPS).

Suryatika, I. B. M., Poniman, S., Manuaba, I. B. P., Yasa, I. W. P. S., \& Sutapa, G. N. (2021). The potential cancer risk on body organs as abdomen CT-scan exposure result. International Journal of Life Sciences, 5(3), 171-178. 


\section{References}

Adler, A., Carlton, R., \& Wold, B. (1992). A comparison of student radiographic reject rates. Radiologic technology, 64(1), 26-32.

Belfiore, A., La Rosa, G. L., La Porta, G. A., Giuffrida, D., Milazzo, G., Lupo, L., ... \& Vigneri, R. (1992). Cancer risk in patients with cold thyroid nodules: relevance of iodine intake, sex, age, and multinodularity. The American journal of medicine, 93(4), 363-369. https://doi.org/10.1016/0002-9343(92)90164-7

Chuninghum, J. (1983). The Physics of Radiology.

Cosnier, S., Le Goff, A., \& Holzinger, M. (2014). Towards glucose biofuel cells implanted in human body for powering artificial $\quad$ organs. Electrochemistry $\quad$ Communications, 38, https://doi.org/10.1016/j.elecom.2013.09.021

Crawford, A. J., McLachlan, D. H., Hetherington, A. M., \& Franklin, K. A. (2012). High temperature exposure increases plant cooling capacity. Current Biology, 22(10), R396-R397. https://doi.org/10.1016/j.cub.2012.03.044

Czvikovszky, T. (2003). Expected and unexpected achievements and trends in radiation processing of polymers. Radiation Physics and Chemistry, 67(3-4), 437-440. https://doi.org/10.1016/S0969806X(03)00081-1

Hardt, J., Appl, U., \& Angerer, J. (1999). Biological monitoring of exposure to pirimicarb: hydroxypyrimidines in human urine. Toxicology letters, 107(1-3), 89-93. https://doi.org/10.1016/S0378-4274(99)00035-1

ICRP. (2011). Recommendations of the International Commission on Radiological Protection Publication 103, Annals of the ICRP, Elsevier Publications, Oxford, UK.

Kamalzadeh, A., Koops, W. J., Van Bruchem, J., Tamminga, S., \& Zwart, D. (1998). Feed quality restriction and compensatory growth in growing sheep: development of body organs. Small Ruminant Research, 29(1), 7182. https://doi.org/10.1016/S0921-4488(97)00111-9

Keyak, J. H., \& Falkinstein, Y. (2003). Comparison of in situ and in vitro CT scan-based finite element model predictions of proximal femoral fracture load. Medical engineering \& physics, 25(9), 781-787. https://doi.org/10.1016/S1350-4533(03)00081-X

Martina, D. (2016). Uji Kolimator Pada Pesawat Sinar-X Merk/Type Mednif/Sf-100By Di Laboratorium Fisika Medik Menggunakan Unit Rmi (Doctoral dissertation, Universitas Negeri Semarang).

Pimblott, S. M., \& LaVerne, J. A. (2007). Production of low-energy electrons by ionizing radiation. Radiation Physics and Chemistry, 76(8-9), 1244-1247. https://doi.org/10.1016/j.radphyschem.2007.02.012

Raidanti, D., Wijayanti, R., \& Wahidin, W. (2021). Influence of health counseling with media leaflets on women of childbearing age (WUS): Knowledge and attitude to conduct PAP smear at midwifery poly in RSPAD Gatot Soebroto Jakarta. International Journal of Health \& Medical Sciences, 4(3), 362-366. https://doi.org/10.31295/ijhms.v4n3.1777

Silvia, H., Milvita, D., Prasetio, H., \& Yuliati, H. (2013). Estimasi Nilai Ctdi Dan Dosis Efektif Pasien Bagian Head, Thorax Dan Abdomen Hasil Pemeriksaan Ct-scan Merek Philips Briliance 6. Jurnal Fisika Unand, 2(2).

Sofiana, L. (2013). Estimasi Dosis Efektif Pada Pemeriksaan Multi Slice CT-Scan Kepala Dan Abdomen Berdasarkan Rekomendasi ICRP 103 (Doctoral dissertation, Brawijaya University).

Strauss, L. J., \& Rae, W. I. (2012). Image quality dependence on image processing software in computed radiography. SA Journal of Radiology, 16(2).

Suryatika, I. B. M., Anggarani, N. K. N., Poniman, S., \& Sutapa, G. N. (2020). Potential Risk of Cancer in Body Organs as Result of Torak CT-scan Exposure. International Journal of Physical Sciences and Engineering, 4(3), 1-6.

Susilo, S., \& Setiowati, L. (2012). Application of Digital Radiography Tools in Photorontgen Service Development. Journal of Mathematics and Natural Sciences, State University of Semarang, 35(2), 145-150.

Sutapa, G. N., Ratini, N. N., Anggarani, N. K. N., \& Kasmawan, I. G. A. (2021). Survival of white blood cells of mice (Mus musculus L) on interval AD with CD post gamma radiation Co-60. International Journal of Health \& Medical Sciences, 4(4). https://doi.org/10.21744/ijhms.v4n4.1786

Sutapa, G. N., Yuliara, I. M., \& Ratini, N. N. (2018). Verification of dosage and radiation delivery time breast cancer (Mammae Ca) with ISIS TPS. International journal of health sciences, 2(2), 78-88.

Tan, R. T., Kuzo, R., Goodman, L. R., Siegel, R., Haasler, G. R., \& Presberg, K. W. (1998). Utility of CT scan evaluation for predicting pulmonary hypertension in patients with parenchymal lung disease. Chest, 113(5), 1250-1256. https://doi.org/10.1378/chest.113.5.1250 
Tsalafoutas, I. A., \& Metallidis, S. I. (2011). A method for calculating the dose length product from CT DICOM images. The British Journal of Radiology, 84(999), 236-243.

Vasen, H. F., Wijnen, J. T., Menko, F. H., Kleibeuker, J. H., Taal, B. G., Griffioen, G., ... \& Khan, P. M. (1996). Cancer risk in families with hereditary nonpolyposis colorectal cancer diagnosed by mutation analysis. Gastroenterology, 110(4), 1020-1027. https://doi.org/10.1053/gast.1996.v110.pm8612988

Suryatika, I. B. M., Poniman, S., Manuaba, I. B. P., Yasa, I. W. P. S., \& Sutapa, G. N. (2021). The potential cancer risk on body organs as abdomen CT-scan exposure result. International Journal of Life Sciences, 5(3), 171-178. https://doi.org/10.53730/ijls.v5n3.1721 


\section{Biography of Authors}

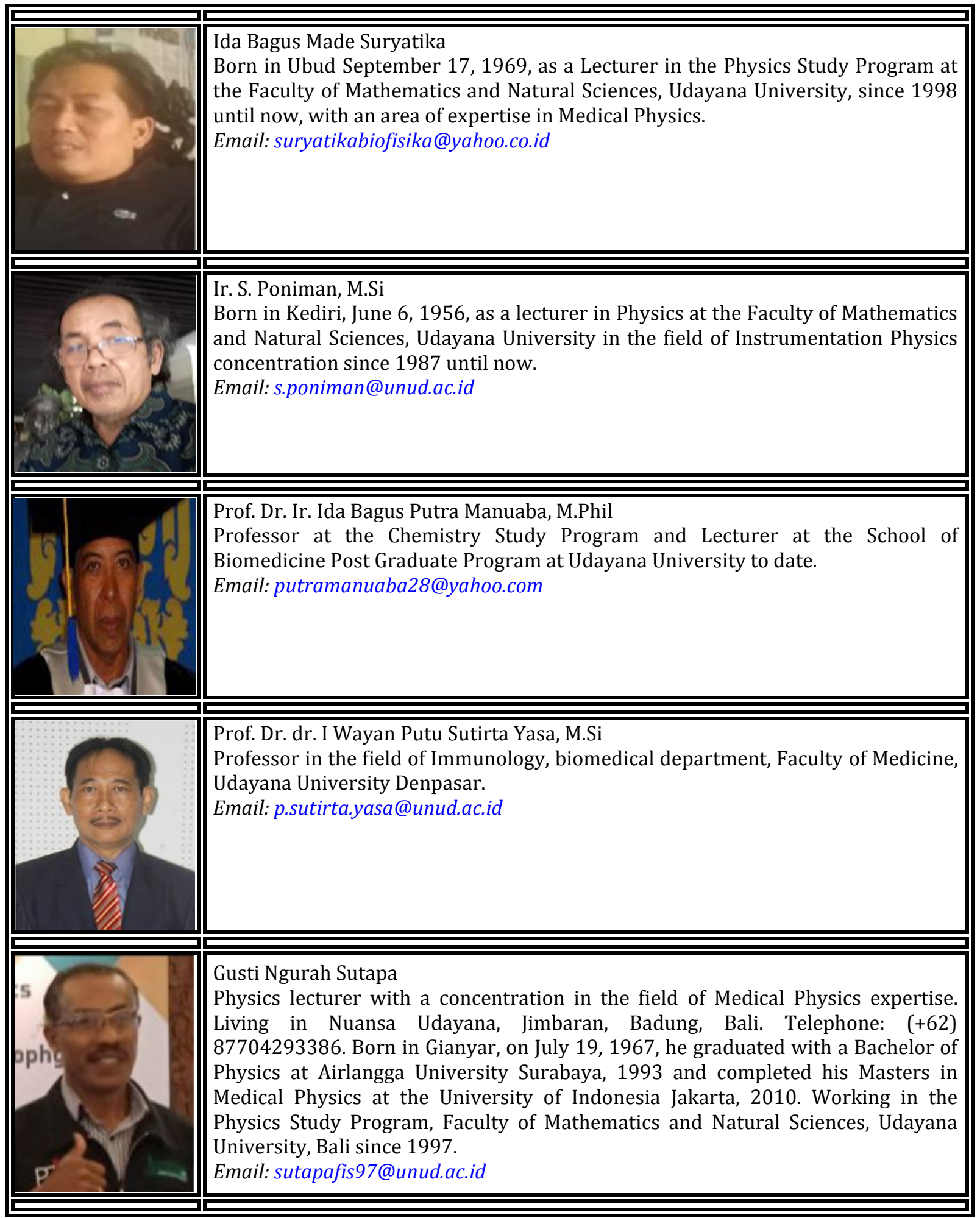

